\title{
Clinicopathological characteristics of multiple intracranial Rosai-Dorfman disease with increased IgG4-positive plasma cells: a report of two cases
}

\author{
Chunhui Zhou ${ }^{1^{*}}$, Hongxiang Ren ${ }^{2 *}$, Liu Hong ${ }^{3^{*}}$, Jianning Zhang ${ }^{1}$, Hongxiang Wang ${ }^{4}$ \\ ${ }^{1}$ Department of Neurosurgery, The Sixth Medical Center of PLA General Hospital, Beijing, China, ${ }^{2}$ Department of Neurosurgery, \\ China-Japan Friendship Hospital, Capital University of Medical, Beijing, China, ${ }^{3}$ Department of Pathology, The Sixth Medical Center \\ of PLA General Hospital, Beijing, China, ${ }^{4}$ Department of Neurosurgery, Changhai Hospital, Naval Military Medical University, \\ Shanghai, China \\ ${ }^{*}$ These authors contributed equally to this work.
}

\begin{abstract}
Rosai-Dorfman disease (RDD) is an uncommon condition characterized by the proliferation of histiocytes and multiple intracranial involvements and it is extremely rare. Here, we present two cases of multiple intracranial RDD mimicking meningioma. These patients underwent surgery for tumour resection and pathological findings revealed an increased number of IgG4-positive plasma cells in RDD. The radiographic appearance and histology may contribute to a diagnostic dilemma, and immunohistochemical and serological examinations are a necessary complement for definitive diagnosis. Treatment protocols pertaining to such types of RDD cases are reviewed. Currently, surgical resection is the most effective therapy, and steroid therapy, radiotherapy, or chemotherapy may be provided as adjuvant treatments in some selected patients.
\end{abstract}

Key words: Rosai-Dorfman disease, multiple intracranial lesions, IgG4, diagnosis, treatment.

\section{Introduction}

Rosai-Dorfman disease (RDD), also known as sinus histiocytosis with massive lymphadenopathy, is a rare, idiopathic, and non-neoplastic histioproliferative disorder of unknown aetiology. Although it mainly affects lymph nodes and manifests with massive painless cervical lymphadenopathy in the presence of fever in young individuals, RDD has also been found to occasionally involve extranodal sites (accounting for about $40 \%$ of RDD cases), including skin, nasal cavity, bone, lung, soft tissue, and sali- vary glands [6]. However, intracranial presentation of this disease is extremely uncommon (approx. 5\%), and as revealed by previous studies, central nervous system (CNS) involvement usually presents as an isolated lesion mimicking meningioma without systemic manifestations [2].

Recently, a few case studies have found that a subset of RDD patients exhibited increased immunoglobulin G4 (IgG4)-positive plasma cells and an elevated lgG4/lgG ratio in the affected organs [56]. These findings suggested that RDD is possibly char- 
Table I. Summary of previously reported cases with intracranial Rosai-Dorfman disease mimicking IgG4-related disease

\begin{tabular}{|c|c|c|c|c|c|c|c|c|}
\hline $\begin{array}{l}\text { Authors } \\
\text { and year }\end{array}$ & No. & $\begin{array}{l}\text { Age } \\
\text { (year) }\end{array}$ & Sex & Location(s) & $\begin{array}{c}\text { IgG4 (cells/ } \\
\text { HPF) }\end{array}$ & $\begin{array}{l}\text { IgG4/ } \\
\text { IgG }\end{array}$ & Treatment(s) & $\begin{array}{c}\text { Outcome } \\
\text { and follow-up }\end{array}$ \\
\hline \multirow{3}{*}{$\begin{array}{l}\text { Menon et al., } \\
2012[34]\end{array}$} & 1 & 55 & $\mathrm{~F}$ & Dural involvement & 86 & $47 \%$ & NA & NA, NA \\
\hline & 2 & 65 & $\mathrm{~F}$ & Dural involvement & 47 & $24 \%$ & NA & $N A, N A$ \\
\hline & 3 & 11 & $\mathrm{~F}$ & Frontal lobe & 10 & $5 \%$ & NA & $\mathrm{NA}, \mathrm{NA}$ \\
\hline $\begin{array}{l}\text { Tauziede- } \\
\text { Espariat et al., } \\
2015[50]\end{array}$ & 4 & 35 & $\mathrm{~F}$ & $\begin{array}{c}\text { Bilateral parieto- } \\
\text { occipital leptomeningeal } \\
\text { involvement }\end{array}$ & $>30$ & $50 \%$ & $\begin{array}{c}\text { Biopsy + steroid } \\
\text { therapy }\end{array}$ & $\begin{array}{l}\text { Completely } \\
\text { recovered, } 6 \text { months }\end{array}$ \\
\hline \multirow[t]{2}{*}{$\begin{array}{l}\text { Yang et al., } \\
2017 \text { [58] }\end{array}$} & 5 & 14 & $\mathrm{~F}$ & $\begin{array}{l}\text { Left petroclival } \\
\text { region }\end{array}$ & 15 & NA & $\begin{array}{c}\text { STR + gamma-knife } \\
\text { surgery }\end{array}$ & $\begin{array}{c}\text { Residual lesion } \\
\text { significantly } \\
\text { retrogressed, } 12 \text { months }\end{array}$ \\
\hline & 6 & 50 & M & Dural involvement & 30 & 20 & $\begin{array}{c}\text { Surgery + steroid } \\
\text { therapy + rituximab }\end{array}$ & $\begin{array}{c}\text { Condition improved, } \\
\text { NA }\end{array}$ \\
\hline \multirow[t]{2}{*}{$\begin{array}{l}\text { Wang et al., } \\
2020[56]\end{array}$} & 7 & 29 & $M$ & $\begin{array}{c}\text { Dural involvement } \\
\text { and subcutaneous } \\
\text { mass }\end{array}$ & $>50$ & 40 & $\begin{array}{c}\text { Surgery }+ \\
\text { steroid therapy }+ \\
\text { cyclophosphamide }\end{array}$ & $\begin{array}{c}\text { Condition improved, } \\
\text { NA }\end{array}$ \\
\hline & 8 & 37 & $M$ & $\begin{array}{l}\text { Sellar region and } \\
\text { orbital cavity }\end{array}$ & $>100$ & $>40$ & Surgery & Remain the same, NA \\
\hline
\end{tabular}

$F$-female, $M$ - male, $N A$ - not available, STR - stereotactic radiotherapy

acterized by some features of IgG4-related disease (IgG4-RD). To date, few intracranial RDD cases with variable infiltration of IgG4-positive cells been reported $[34,50,56,58]$ (Table I). Herein, we provide clinicopathological features of additional two multiple meningeal RDD cases with a highly increased level of IgG4-positive plasma cells in our institute to facilitate a comprehensive understanding of these diseases.

\section{Case 1}

A male patient aged 47 was admitted to our hospital with a 4-month history of intermittent right upper extremity numbness and an acute focal seizure of the right upper extremity and right face. Neurological examination was normal and no superficial lymph node enlargement or fever was found. A magnetic resonance imaging $(\mathrm{MRI})$ revealed multiple carpet-like masses in the left frontal, parietal, and temporal regions and bilateral occipital meningeal. All lesions were slightly hypointense on T1-weighted images and hyperintense on T2-weighted images, with homogeneous enhancement and a dural tail sign on contrast (Fig. 1A-C). Obvious cerebral oedema was seen around the left temporal lesion, the maximum diameter of which was approximately 6 $\mathrm{cm}$. Computed tomography (CT) scan demonstrated neither bone destruction nor hyperplasia. Preoperative diagnosis suggested the possibility of multiple intracranial meningiomas or metastases. Then, the patient underwent a left frontotemporal craniotomy to remove the giant mass, which was relatively avascular, yellowish, and extremely hard, with an unclear boundary between parts of the lesion and the cortex. Histopathological examination revealed cellular infiltrates of abundant lymphocytes, plasma cells, and histiocytes. On immunohistochemical staining, the histiocytes were strongly positive for S-100 protein, the monocyte-associated antigen CD68, and CD163 (Fig. 2A-C), but negative for BRAFV600E, Vimentin, EMA, CD34, GFAP, Olig-2, $\mathrm{PR}, \mathrm{BCL}-2$, and P53, and Ki67 was less than $4 \%$. Emperipolesis was confirmed by the presence of intact intracytoplasmic CD3 and CD20 positive lymphocytes of the histiocytes. The average number of IgG4-positive plasma cells was higher than 35 by high-power field (HPF) (Fig. 2D). The ratio of IgG4+ to IgG+ cells was about $50 \%$, and IgG+ cells were positively stained by both Kappa and Lambda. The serum lgG4 level was detected normally at $21.4 \mathrm{mg} / \mathrm{dl}$ (range: 1-291 $\mathrm{mg} / \mathrm{dl}$ ). Based on these findings, thus the final diagnosis was RDD. Unresected small lesions located in the bilateral occipital region had not progressed during the two-year follow-up.

\section{Case 2}

A 19-year-old man presented with a history of headache and dysphagia for three months. He had no previous medical history. Physical examination 

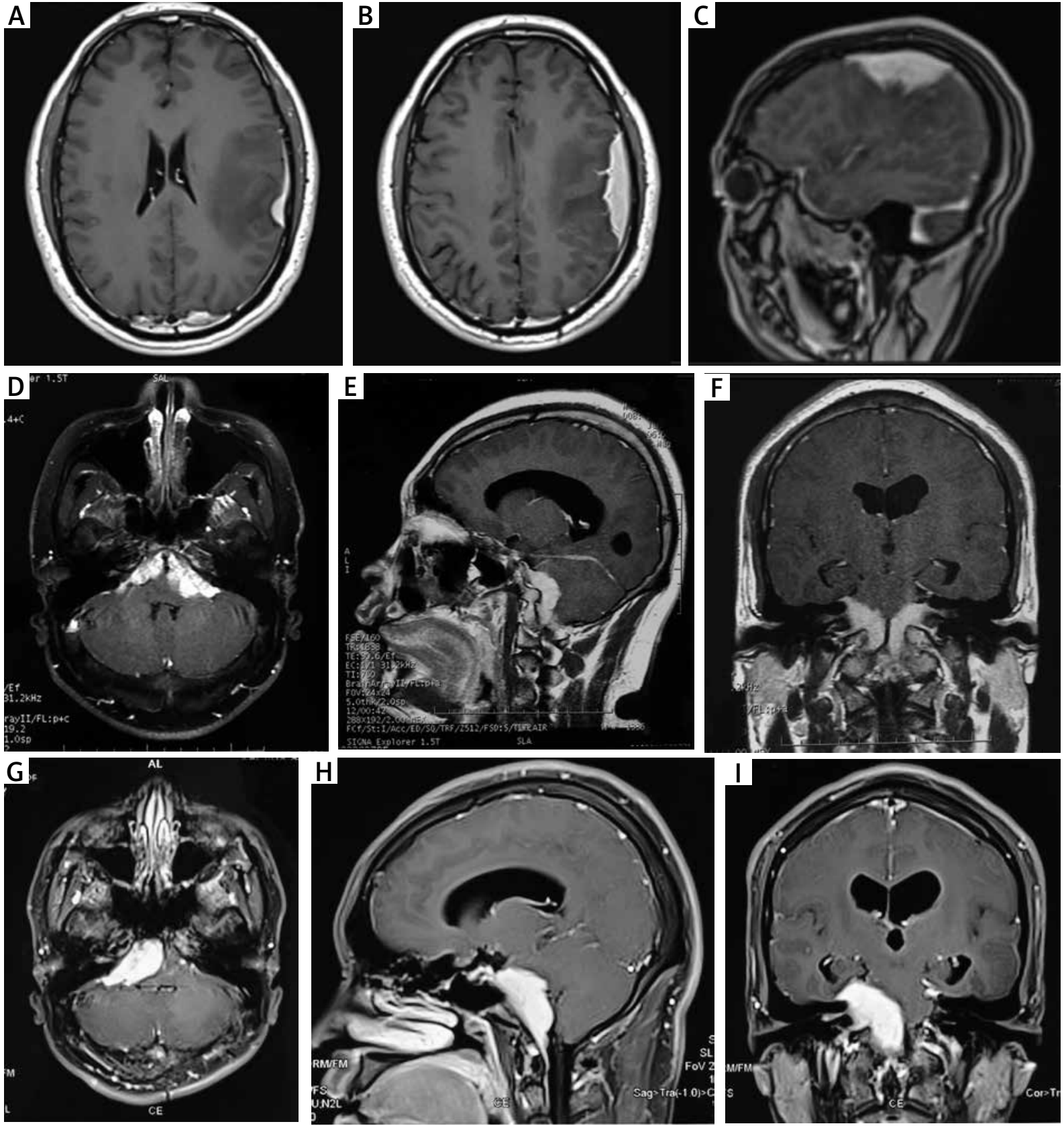

Fig. 1. Neuroimaging findings. A-C) T1-weighted contrast-enhanced MRI scan showing multiple masses in the left frontal, parietal, and temporal regions and bilateral occipital meningeal. D-F) Enhancement lesions in bilateral cerebellopontine angle regions and extending into the left foramen magnum. G-I) Progression of the lesion in the right cerebellopontine angle region.

found mild difficulty swallowing revealing a posterior cranial nerves deficit. MRI showed two homogenous contrast enhancement masses occupying bilateral cerebellopontine angle (CPA) regions and extending into the left foramen magnum (Fig. 1D-F). All lesions appeared isointense to the brain in $\mathrm{T} 1$ - and
T2-weighted sequences, without bone erosion or destruction in CT scan. The diagnosis of meningioma was made before surgery. As the mass effect of the left lesion on the brain stem was evident, the excision of the left lesion was performed first with intraoperative neurophysiological monitoring 

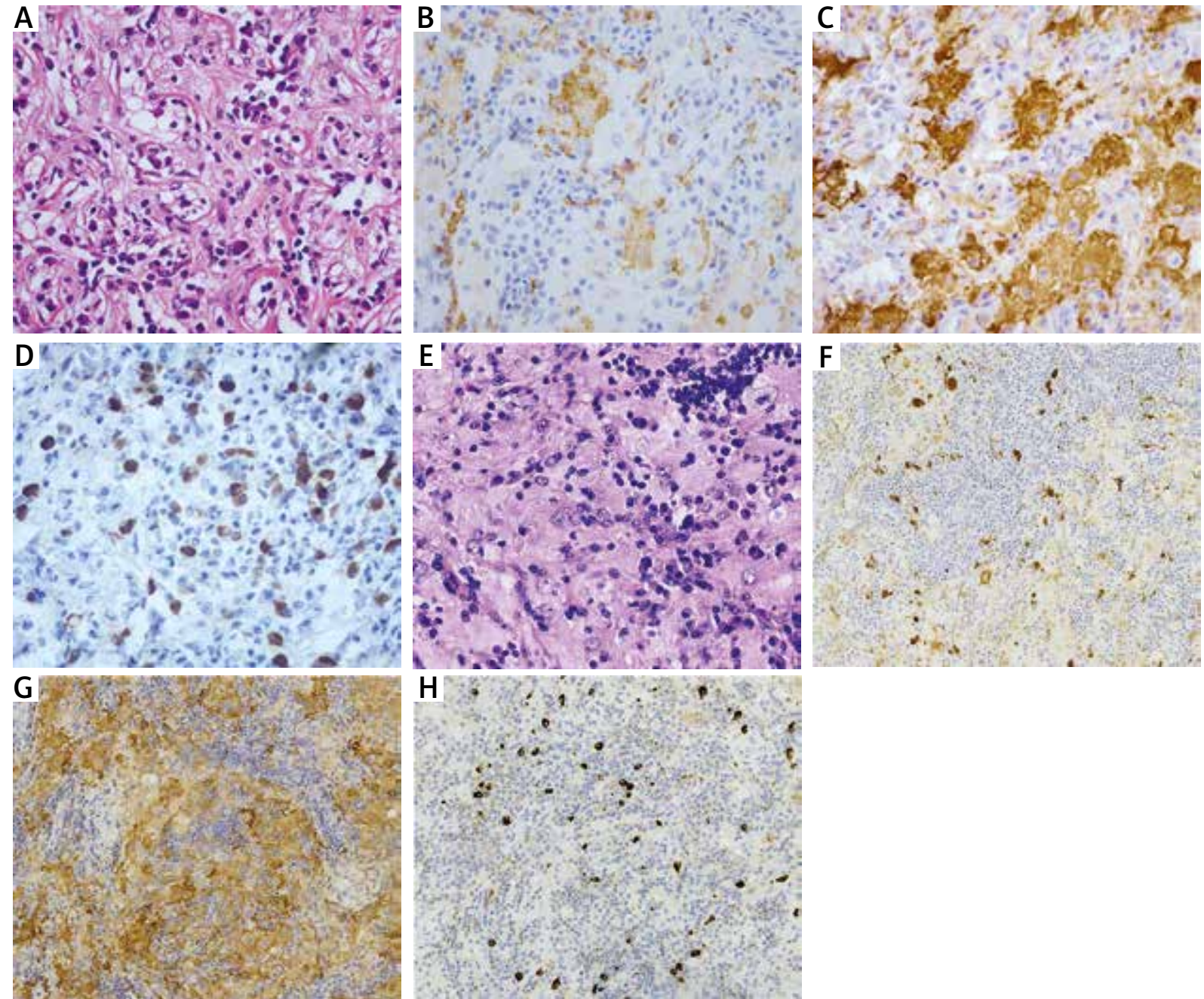

Fig. 2. Histopathological findings. A, E) Histologic sections demonstrating lymphocytes within the abundant cytoplasm in histiocytes (haematoxylin and eosin stain, 100x). B, F) Positive reactivity for CD68 protein (100x). C, G) Positive reactivity for S-100 protein (100x). D, H) Plasmacytes showing about 35/HPF (D) and 15/HPF (H) IgG4 positive, respectively.

through a far lateral approach. The lesion was red and extremely hard and grew in a creeping type with a rich blood supply. Histopathological findings included the proliferation of histiocytic cells and infiltration of lymphocytes and plasma cells (Fig. 2E). Immunohistochemical staining revealed strongly positive for S-100 and CD68 in the large histiocytes (Fig. 2F, G), and a significant portion of plasma cells was immunoreactive to lgG4 (15/HPF) and the ratio of IgG4+ to IgG+ cells was about 35\% (Fig. 2H). The postoperative lgG4 serum level was normal at $36.6 \mathrm{mg} / \mathrm{dl}$. After surgery, the patient had left facial paralysis (House-Brackmann [H-B] II degree) and a relatively mild hearing loss in his left ear, and the symptom of dysphagia also remained mild. Ionizing radiation was given to prevent further neurological impairment. According to the suggestion of a multidisciplinary team in our hospital, the patient received steroid treatment (prednisone of $30 \mathrm{mg} \mathrm{qd}$ ) for one month. However, during the follow-up of the next nine months, the patient gradually developed a hearing loss in his right ear. MRI showed progression of the right lesion (Fig. 1G-I). Subsequently, he underwent excision of the lesion via the right suboccipital retrosigmoid approach. Pathological examination demonstrated typical features of RDD with increased lgG4-positive plasma cells (20/HPF) and a high ratio of IgG4/lgG (40\%). Postoperative MRI 
confirmed total removal of the lesion, and no recurrence occurred at the one-year follow-up. However, the patient had not completely recovered from his bilateral hearing loss, right facial paralysis ( $\mathrm{H}-\mathrm{B}$ III degree), and dysphagia.

\section{Discussion}

Rosai-Dorfman disease is an uncommon disorder that rarely involves CNS, moreover, multiple intracranial lesions have also been seldom reported. As indicated in previous studies, this specific type of RDD has a propensity to occur in males (male : female $3.3: 1$ ) and the age of patients at diagnosis ranges from 2 to 72 years $[1,4,7,8,10,13,16,20,25-27,31-33,35,38$ $41,44,48,51,53,55]$ (Table II). Presenting symptoms associated with neurological deficits and mass effects depend on the location, size, and growth pattern of lesions. The common sites of multiple RDD are reported in cerebral convexity, parasellar and suprasellar regions, cranial base, and supratentorial ventricular system. In our study, we presented a case with lesions involving cerebral convexity and a patient with masses in bilateral CPA regions.
Radiologically, the typical appearance of multiple RDD is dural-based, extra-axial, and well-circumscribed enhancing masses mimicking meningioma in the cranium. On CT scans, the lesions show homogeneous hyperdensity or isodensity with possible hypodense perilesional cerebral oedema. Hyperostosis, bone erosion, and calcification are usually absent but can be common in meningioma. Moreover, digital subtraction angiography shows hypervascularity in a majority of meningiomas which are largely fed by branches of the external carotid artery or the internal carotid artery system [52]. In contrast, RDD varies in blood supply from avascularity to abundant vascularity [29]. MRI plays an important role in RDD diagnosis. When viewed on T1-weighted images, they usually appear as isointense or hyperintense masses with clear borders relative to the brain parenchyma, while T2-weighted and FLAIR sequences show an isointense signal with possible intralesional foci of low signal intensity, which may be helpful to distinguish RDD from meningioma. It is presumed that the specific hypointense foci are formed as a result of free radicals produced by

Table II. Published cases with multiple intracranial Rosai-Dorfman disease in the last 30 years

\begin{tabular}{|c|c|c|c|c|c|c|}
\hline $\begin{array}{l}\text { Authors } \\
\text { and year }\end{array}$ & No. & $\begin{array}{c}\text { Age } \\
\text { (year) }\end{array}$ & Sex & Locations & Treatment(s) & $\begin{array}{c}\text { Outcome } \\
\text { and follow-up }\end{array}$ \\
\hline $\begin{array}{l}\text { Kim et al., } \\
1995 \text { [25] }\end{array}$ & 1 & 50 & M & $\begin{array}{c}\text { Lesions involving the right parietal } \\
\text { convexity }\end{array}$ & Complete removal & $\begin{array}{l}\text { No residual or recurrent } \\
\text { lesion, } 6 \text { months }\end{array}$ \\
\hline $\begin{array}{l}\text { Resnick et al., } \\
1996[41]\end{array}$ & 2 & 38 & M & $\begin{array}{l}\text { Lesions involving the frontal convexity } \\
\text { in both sides and the left CPA region }\end{array}$ & $\begin{array}{l}\text { Partial resection of the } \\
\text { posterior fossa mass }\end{array}$ & Stable, 18 months \\
\hline $\begin{array}{l}\text { Udono et al., } \\
1999 \text { [53] }\end{array}$ & 3 & 67 & $\mathrm{~F}$ & $\begin{array}{l}\text { A large lesion in the right frontal } \\
\text { parasagittal area and several satellite } \\
\text { lesions involving the right parietal } \\
\text { convexity, frontal base, right sphenoid } \\
\text { ridge, left frontal convexity, tentorium, } \\
\text { and pharynx }\end{array}$ & $\begin{array}{l}\text { Removal of the frontal } \\
\text { convexity mass }\end{array}$ & $\begin{array}{l}\text { No regrowth of the } \\
\text { satellite lesions, } \\
20 \text { months }\end{array}$ \\
\hline $\begin{array}{l}\text { Chen, } 2003 \\
\text { [10] }\end{array}$ & 4 & 70 & M & $\begin{array}{l}\text { Lesions involving the right parietal and } \\
\text { suprasellar regions }\end{array}$ & $\begin{array}{l}\text { Resection of the } \\
\text { right parietal mass } \\
\text { and biopsy for the } \\
\text { suprasellar lesion }\end{array}$ & $\begin{array}{l}\text { Died of respiratory } \\
\text { failure, } 3 \text { years after the } \\
\text { second craniotomy }\end{array}$ \\
\hline $\begin{array}{l}\text { Purav et al., } \\
2005[38]\end{array}$ & 5 & 50 & M & Multiple intraparenchymal lesions & $\begin{array}{l}\text { Biopsy for the right } \\
\text { parietal lesion }\end{array}$ & $\begin{array}{l}\text { Died, } 10 \text { days post- } \\
\text { operation }\end{array}$ \\
\hline $\begin{array}{l}\text { Gupta et al., } \\
2006[16]\end{array}$ & 6 & 15 & M & $\begin{array}{l}\text { Bilateral petroclival lesions extending } \\
\text { to the cavernous sinus region } \\
\text { bilaterally and a lesion in the bilateral } \\
\text { anterior frontal parasagittal region }\end{array}$ & $\begin{array}{l}\text { Steroid therapy + near- } \\
\text { total resection of the } \\
\text { lesion in the left side and } \\
\text { gross total resection of } \\
\text { the lesion in the right side }\end{array}$ & $\begin{array}{l}\text { A small residual tumor } \\
\text { (stable), } 12 \text { months }\end{array}$ \\
\hline $\begin{array}{l}\text { McPherson } \\
\text { et al., } 2006 \\
\text { [33] }\end{array}$ & 7 & 53 & M & $\begin{array}{c}\text { Multiple skull base lesions including } \\
\text { a lesion at the planum sphenoidale } \\
\text { and tuberculum sellae and bilateral } \\
\text { lesions from the CPA to the foramen } \\
\text { magnum }\end{array}$ & $\begin{array}{l}\text { Resection of the planum } \\
\text { sphenoidale/tuberculum } \\
\text { sellae lesion debulked } \\
\text { maximally + steroid } \\
\text { therapy }\end{array}$ & $\begin{array}{l}\text { Marked resolution of } \\
\text { the remaining lesions, } \\
11 \text { months }\end{array}$ \\
\hline
\end{tabular}


Table II. Cont.

\begin{tabular}{|c|c|c|c|c|c|c|}
\hline $\begin{array}{l}\text { Authors } \\
\text { and year }\end{array}$ & No. & $\begin{array}{c}\text { Age } \\
\text { (year) }\end{array}$ & Sex & Locations & Treatment(s) & $\begin{array}{l}\text { Outcome } \\
\text { and follow-up }\end{array}$ \\
\hline $\begin{array}{l}\text { Russo et al., } \\
2009[43]\end{array}$ & 8 & 72 & M & Bilateral frontobasal lesions & $\begin{array}{l}\text { Resection of the two } \\
\text { masses }\end{array}$ & $\begin{array}{l}\text { Free of neurological } \\
\text { symptoms, } 14 \text { months }\end{array}$ \\
\hline $\begin{array}{l}\text { La Barge 3rd } \\
\text { et al., } 2009 \\
{[27]}\end{array}$ & 9 & 51 & M & $\begin{array}{c}\text { Lesions in bilateral CPA regions } \\
\text { extending to the cervicomedullary } \\
\text { junction }\end{array}$ & NA & $N A, N A$ \\
\hline $\begin{array}{l}\text { Symss et al., } \\
2010[48]\end{array}$ & 10 & 21 & M & $\begin{array}{c}\text { Lesions involving the tentorium } \\
\text { infratentorially on both sides and the } \\
\text { cavernous sinuses }\end{array}$ & $\begin{array}{l}\text { Subtotal resection of } \\
\text { the right lesion }\end{array}$ & $\begin{array}{l}\text { Progression of the lesion } \\
\text { bilaterally, } 6 \text { months }\end{array}$ \\
\hline \multirow[t]{2}{*}{$\begin{array}{l}\text { Raslan et al., } \\
2011[40]\end{array}$} & 11 & 50 & M & $\begin{array}{l}\text { Lesions involving bilateral paracavernous } \\
\text { regions, right temporal lobe, left frontal } \\
\text { convexity, and spinal canal at L1 }\end{array}$ & $\begin{array}{l}\text { Resection of brain and } \\
\text { spinal lesions }\end{array}$ & $N A, N A$ \\
\hline & 12 & 54 & M & $\begin{array}{c}\text { Sellar and suprasellar lesions, bilateral } \\
\text { CPA lesions extending into the upper } \\
\text { spinal canal }\end{array}$ & $\begin{array}{l}\text { Surgical resection of the } \\
\text { sellar lesion + steroids } \\
\text { therapy }\end{array}$ & $\mathrm{NA}, \mathrm{NA}$ \\
\hline $\begin{array}{l}\text { Nalini et al., } \\
2012[35]\end{array}$ & 13 & 35 & M & $\begin{array}{c}\text { Lesions involving parasellar, } \\
\text { tuberculum sellae, planum } \\
\text { sphenoidale, and tentorium, and } \\
\text { inferiorly along the CPA region and } \\
\text { clivus into the spinal canal }\end{array}$ & $\begin{array}{l}\text { Steroid therapy + biopsy } \\
+ \text { radiotherapy }\end{array}$ & Disease progression, NA \\
\hline $\begin{array}{l}\text { Catalucci } \\
\text { et al., } 2012[8]\end{array}$ & 14 & 57 & M & $\begin{array}{l}\text { Lesions involving the cerebral falx within } \\
\text { the interhemispheric fissure, the right } \\
\text { perirolandic region, the right temporo- } \\
\text { polar/sphenoidal and insular region, } \\
\text { the left tentorium, the right petroclival } \\
\text { region, and the lateral ventricle }\end{array}$ & $\begin{array}{l}\text { Surgical resection of the } \\
\text { infratentorial petroclival } \\
\text { right mass }\end{array}$ & $\mathrm{NA}, \mathrm{NA}$ \\
\hline $\begin{array}{l}\text { Camp et al., } \\
2012[7]\end{array}$ & 15 & 31 & $\mathrm{~F}$ & $\begin{array}{l}\text { Lesions involving the left frontal } \\
\text { region, the right frontal white matter, } \\
\text { and the right parietal region }\end{array}$ & $\begin{array}{l}\text { Resection of the left } \\
\text { frontal lesion }+ \text { steroid } \\
\text { therapy }\end{array}$ & $\begin{array}{l}\text { No evidence of disease } \\
\text { recurrence, } 12 \text { months }\end{array}$ \\
\hline $\begin{array}{l}\text { Antuna } \\
\text { Ramos et al., } \\
2012[4]\end{array}$ & 16 & 10 & $F$ & $\begin{array}{l}\text { Intracranial lesions involving the right } \\
\text { parasagittal basal frontal region, the } \\
\text { left middle cerebellar peduncle, and } \\
\text { the right ventral pons } \\
\text { Intraspinal lesions at T9-T10, T6-T7 } \\
\text { and T10-T11 levels }\end{array}$ & $\begin{array}{c}\text { Complete removal } \\
\text { of three frontal brain } \\
\text { lesions, partial resection } \\
\text { of the intraspinal lesion } \\
\text { and the cerebellopontine } \\
\text { lesion + steroid therapy + } \\
\text { radiotherapy }\end{array}$ & $\begin{array}{l}\text { Died, } 5 \text { months after } \\
\text { the initial diagnosis }\end{array}$ \\
\hline $\begin{array}{l}\text { Abdel-Razek } \\
\text { et al., } 2013[1]\end{array}$ & 17 & 43 & M & $\begin{array}{l}\text { Lesions involving the right frontal } \\
\text { convexity, the left frontal region, } \\
\text { cerebral falx, the anterior clinoid } \\
\text { process, and the right petrous bone }\end{array}$ & $\begin{array}{l}\text { Total resection of the } \\
\text { large frontal lesion }\end{array}$ & $N A, N A$ \\
\hline $\begin{array}{l}\text { Forest et al., } \\
2013[13]\end{array}$ & 18 & 38 & M & $\begin{array}{l}\text { Ethmoidal, frontal, and cerebral falx } \\
\text { lesions }\end{array}$ & Resection & NA, 8 years \\
\hline \multirow[t]{2}{*}{$\begin{array}{l}\text { Sandoval-Sus } \\
\text { et al., } 2014 \\
{[44]}\end{array}$} & 19 & 51 & M & $\begin{array}{l}\text { Lesions involving bilateral internal } \\
\text { auditory canals and CPA regions and } \\
\text { the foramen magnum }\end{array}$ & $\begin{array}{l}\text { Partial surgical resection } \\
+ \text { radiotherapy }\end{array}$ & Stable, 7 months \\
\hline & 20 & 18 & M & $\begin{array}{l}\text { Multiple brain, base of skull, } \\
\text { and cervical spine masses }\end{array}$ & $\begin{array}{l}\text { Partial surgical resection } \\
\text { followed + chemotherapy } \\
\text { (V, MTX, 6-MP, and } \\
\text { prednisone) + radiotherapy }\end{array}$ & Stable, 7 years \\
\hline $\begin{array}{l}\text { Lüdemann et } \\
\text { al., } 2015 \text { [31] }\end{array}$ & 21 & 2 & M & $\begin{array}{c}\text { Lesions involving bilateral frontal } \\
\text { lobes and the occipital horn of the left } \\
\text { ventricle }\end{array}$ & $\begin{array}{l}\text { Steroid therapy + partial } \\
\text { resection of the occipital } \\
\text { intraventricular mass }\end{array}$ & Stable, 16 months \\
\hline $\begin{array}{l}\text { Tian et al., } \\
2015 \text { [51] }\end{array}$ & 22 & 6 & F & $\begin{array}{c}\text { Lesions in the lateral ventricle, } \\
\text { tentorium of cerebellum on both sides } \\
\text { and in frontal falx }\end{array}$ & $\begin{array}{l}\text { Total resection of the } \\
\text { largest mass in the left } \\
\text { ventricle }\end{array}$ & Stable, NA \\
\hline
\end{tabular}


Table II. Cont.

\begin{tabular}{|c|c|c|c|c|c|c|}
\hline $\begin{array}{l}\text { Authors } \\
\text { and year }\end{array}$ & No. & $\begin{array}{l}\text { Age } \\
\text { (year) }\end{array}$ & Sex & Locations & Treatment(s) & $\begin{array}{l}\text { Outcome } \\
\text { and follow-up }\end{array}$ \\
\hline \multirow[t]{2}{*}{$\begin{array}{l}\text { Luo et al., } \\
2017 \text { [32] }\end{array}$} & 23 & 41 & $M$ & $\begin{array}{l}\text { Lesions involving ventricles, left } \\
\text { parasellar and CPA region }\end{array}$ & $\begin{array}{l}\text { Complete resection } \\
\text { of the fourth ventricle } \\
\text { lesion + steroid therapy } \\
\text { + radiotherapy }\end{array}$ & $\begin{array}{l}\text { Residual lesions } \\
\text { markedly enlarged, } \\
42 \text { months }\end{array}$ \\
\hline & 24 & 31 & M & $\begin{array}{l}\text { Lesions involving bilateral sphenoidal } \\
\text { crest, right parasellar, cavernous sinus, } \\
\text { bilateral frontoparietal meningeal and } \\
\text { foramen magnum }\end{array}$ & $\begin{array}{l}\text { Resection of the } \\
\text { right parasellar mass } \\
\text { + steroid therapy + } \\
\text { radiotherapy }\end{array}$ & $\begin{array}{l}\text { Residual lesions slightly } \\
\text { enlarged, } 24 \text { months }\end{array}$ \\
\hline \multirow[t]{3}{*}{$\begin{array}{l}\text { Jiang and } \\
\text { Jiang, } 2018 \\
{[20]}\end{array}$} & 25 & 39 & $M$ & $\begin{array}{c}\text { Lesions involving the left frontal lobe } \\
\text { and right frontoparietal meningeal } \\
\text { regions }\end{array}$ & $\begin{array}{l}\text { Radiotherapy }+ \text { total } \\
\text { resection of lesions in } \\
\text { two-stage surgery }\end{array}$ & $\begin{array}{l}\text { No recurrence, } \\
78 \text { months }\end{array}$ \\
\hline & 26 & 53 & M & $\begin{array}{l}\text { Lesions involving the left parietal, } \\
\text { temporal, occipital meningeal regions }\end{array}$ & $\begin{array}{l}\text { Resection of the largest } \\
\text { left occipital mass }\end{array}$ & $\begin{array}{l}\text { No size increases } \\
\text { of residual lesions, } \\
8 \text { months }\end{array}$ \\
\hline & 27 & 9 & F & $\begin{array}{c}\text { Lesions involving the right parietal } \\
\text { meningeal region }\end{array}$ & Total resection & $\begin{array}{l}\text { No recurrence, } \\
42 \text { months }\end{array}$ \\
\hline $\begin{array}{l}\text { Krueger et al., } \\
2019 \text { [26] }\end{array}$ & 28 & 52 & $\mathrm{~F}$ & $\begin{array}{c}\text { Lesions involving the bilateral } \\
\text { paramidline frontal and right parietal } \\
\text { lobes at the vertex, left frontal lobe } \\
\text { near the vertex, bilateral posterior } \\
\text { parietal lobes, and bilateral frontal- } \\
\text { temporal lobes }\end{array}$ & $\begin{array}{l}\text { Gross total resection of } \\
\text { the largest lesion in the } \\
\text { right frontal-temporal } \\
\text { region }\end{array}$ & Stable, 3 months \\
\hline $\begin{array}{l}\text { Qin et al., } \\
2019 \text { [39] }\end{array}$ & 29 & 43 & M & $\begin{array}{l}\text { Lesions involving frontal falx, parietal } \\
\text { falx and tentorium cerebelli, and } \\
\text { intraspinal dural T3 level }\end{array}$ & $\begin{array}{l}\text { Resection of the } \\
\text { intraspinal lesion }+ \\
\text { steroid therapy }\end{array}$ & Stable, 2 years \\
\hline $\begin{array}{l}\text { Wang et al., } \\
2019[55]\end{array}$ & 30 & 57 & $\mathrm{~F}$ & $\begin{array}{c}\text { Lesions involving bilateral petroclival, } \\
\text { parasellar regions }\end{array}$ & $\begin{array}{l}\text { Subtotal resection of } \\
\text { the lesion in the left } \\
\text { basement of anterior } \\
\text { cranial fossa }\end{array}$ & $\begin{array}{l}\text { Alive with disease, } \\
18 \text { months }\end{array}$ \\
\hline
\end{tabular}

CPA - cerebellopontine angle, $F$-female, $L$ - lumbar, $M$ - male, $N A$ - not available, $T$-thoracic

macrophages during active phagocytosis [53]. Contrast enhancement is usually marked and presents as inhomogeneous or homogeneous after contrast administration, but can also be little or absent in some cases [18]. The dural tail sign is demonstrated in most cases, however, few purely intraparenchymal RDD cases without dural attachment do not have the classical characteristic, which further increases the difficulty of differential diagnosis [5,14,21]. Newer types of MRI sequences can be used for a better preoperative evaluation as recommended by some authors. On apparent diffusion coefficient maps, RDD displays a higher signal value than lymphoma but lower than meningioma [9]. Magnetic resonance spectroscopy combined with the perfusion profile has particular specificity for some patients, which suggests RDD as an inflammatory rather than a neoplastic process $[7,48]$. Differentials from imaging diagnosis should consider meningioma, lymphoma, metastases, Wegener's granulomatosis, sarcoidosis, Langerhans cell histiocytosis, and pseudotumour.

Definite diagnosis of RDD is totally dependent on histopathological and immunohistochemical examinations. Microscopically, lymphoid follicles with germinal centres, fibrosis, sclerosis, and fewer histiocytes is a prominent feature that is consistent in extra-nodal RDD [21]. Another typical finding is seen as phagocytic vacuoles of intact and viable lymphocytes within the cytoplasm of histiocytes, but this phenomenon of emperipolesis is present in only $70 \%$ of cases and is less often found in CNS RDD than nodal RDD [38]. The staining of histiocytes is positive for CD68 and S-100, but negative for CD1a and EMA, which has important diagnostic values and help rule out other histiocytic diseases and meningioma. Immunoactivities of CD3 and CD20 indicate mixed populations of $B$ and $T$ lymphocytes in the background. Positive staining of Kappa and Lambda 
light chain shows polytypic staining in the plasma cell infiltrates, which excludes the diagnosis of plasmacytoma with monoclonal plasma cell infiltrates.

However, the presence of a high proportion of IgG4+ plasma cells in RDD requires the exclusion of IgG4-RD in the diagnostic process. IgG4-RD is a multi-organ immune-mediated fibroinflammatory condition characterized by specific clinical, serological, and pathological features involving tumefactive tissue, elevated serum IgG4 level, lymphoplasmacytic infiltration enriched in IgG4+ plasma cells, storiform fibrosis, and obliterative phlebitis [22,23]. Though the enrichment of IgG4+ plasma cells and increased lgG4/lgG ratio in RDD mimic some characteristics of IgG4-RD, the former lacks storiform fibrosis and obliterative phlebitis. Elevated serum IgG4 concentration has also been found in some RDD cases, but in general, the level is still lower than that in IgG4-RD patients $[30,56]$. Moreover, negatively stained S-100 and CD68 and higher number of Foxp3+ regulatory T cell infiltration in the IgG4-RD group, while neoplastic point mutations affecting KRAS, NRAS, SMAD4, ARAF, or MAP2K1 occurring in 33-50\% of RDD cases but not IgG4-RD, provide evidence that the two entities are apparently different from each other $[12,15,30,46]$.

Sporadic RDD frequently presents a self-limited clinical course, with up to $50 \%$ of cases having spontaneous remission without any therapy [6]. However, spontaneous resolution is not observed in RDD patients with CNS involvement [44]. Consensus on the management of these RDDs should be reached to confer benefit in patients. Currently, long-term satisfactory results can be obtained from surgical intervention, which is aimed at gross total excision (GTR), in a majority of isolated intracranial RDD cases [13], but recurrence still occurs in about $14 \%$ of patients receiving initial GTR alone over a mean of 10.1 years [2]. In cases of disease located in relatively less accessible regions such as the petroclival or clival area or with multiple lesions, subtotal excision or biopsy or single resection of single foci will be performed sometimes, which significantly increases risks of RDD growth and progression, then close follow-up with clinical and radiological observation is strongly recommended and adjuvant treatments can also be considered.

Systemic steroids are the preferred treatment advocated by few investigators for residual or refractory intracranial or even non-surgically RDD lesions. However, only a portion of cases may benefit from this therapeutic regimen, moreover, in the subgroup of RDD mimicking IgG4-RD, response to steroids is not as good as that in IgG4-RD [11,33,47,56,59]. Once the steroid therapy fails, most patients need treatment of high intensity, such as combining with radiotherapy or chemotherapy or using immunosuppressive drugs $[45,57]$. Radiation offered as fractionated therapy or stereotactic radiotherapy has been used in a few cases. However, no standard doses have yet been established, and the response to radiotherapy varies in patients from poor control to complete disappearance of the lesion $[11,17,24,37,44]$. Many chemotherapy agents including cytarabine, methotrexate, 6-mercaptopurine, anthracyclines, vinca alkaloids, 2-chlorodeoxyadenosine, and etoposide have been tried for RDD with mixed results $[11,19,42,49,57]$. In general, chemotherapy has not provided significant efficacy in the long-term remission of RDD lesions. Additionally, immuno-modulators like interferon- and targeted therapies, such as Imatinib and Rituximab, have also been introduced in the management of RDD, but sufficient evidence is currently lacking to support intracranial disease control by these treatments $[3,28,36,54]$.

\section{Conclusions}

Multiple intracranial RDD mimicking IgG4-RD is an extremely rare disease. Our study underlines the pivotal roles of histopathological and immunohistochemical examinations in its definitive diagnosis and provides comprehensive understanding through clinical manifestations, laboratory parameters, imaging findings, and other pathological characteristics. Maximum safe surgical removal is the preferred treatment approach for almost all patients, as spontaneous regression has not been observed in cases of CNS involvement. Steroids, radiation therapy, and chemotherapy reserve treatment options for residual or refractory RDD lesions, but their variable efficacies should be optimized in future investigations.

\section{Acknowledgements}

This work was supported by the National Natural Science Foundation of China (No. 81902538) and the Shanghai Sailing Program (19YF1448200).

\section{Disclosure}

The authors report no conflict of interest. 


\section{References}

1. Abdel-Razek M, Matter GA, Azab WA, Katchy KC, Mallik AA. Isolated intracranial Rosai-Dorfman disease: report of two cases and a review of the literature. Turk Neurosurg 2013; 23: 509-513.

2. Adeleye AO, Amir G, Fraifeld S, Shoshan Y, Umansky F, Spektor S. Diagnosis and management of Rosai-Dorfman disease involving the central nervous system. Neurol Res 2010; 32: 572-578.

3. Alqanatish JT, Houghton K, Bond M, Senger C, Tucker LB. Rituximab treatment in a child with rosai-dorfman disease and systemic lupus erythematosus. J Rheumatol 2010; 37: 1783-1784.

4. Antuna Ramos A, Alvarez Vega MA, Alles JV, Antuna Garcia MJ, Meilan Martinez A. Multiple involvement of the central nervous system in Rosai-Dorfman disease. Pediatr Neurol 2012; 46: 54-56.

5. Beros V, Houra K, Rotim K, Zivkovic DJ, Cupic H, Kosec A. Isolated cerebellar intraparenchymal Rosai-Dorfman disease--case report and review of literature. Br I Neurosurg 2011; 25: 292-296.

6. Bruce-Brand C, Schneider JW, Schubert P. Rosai-Dorfman disease: an overview. J Clin Pathol 2020; 73: 697-705.

7. Camp SJ, Roncaroli F, Apostolopoulos V, Weatherall M, Lim S, Nandi D. Intracerebral multifocal Rosai-Dorfman disease. J Clin Neurosci 2012; 19: 1308-1310.

8. Catalucci A, Lanni G, Ventura L, Ricci A, Galzio RJ, Gallucci M. A rare case of intracranial rosai-dorfman disease mimicking multiple meningiomas. A case report and review of the literature. Neuroradiol I 2012; 25: 569-574.

9. Cheng X, Cheng JL, Gao AK. A study on clinical characteristics and magnetic resonance imaging manifestations on systemic Rosai-Dorfman disease. Chin Med J (Engl) 2018; 131: 440-447.

10. Chen KT. Crush cytology of Rosai-Dorfman disease of the central nervous system. A report of 2 cases. Acta Cytol 2003; 47: 1111-1115.

11. Cooper SL, Jenrette JM. Rosai-Dorfman disease: management of CNS and systemic involvement. Clin Adv Hematol Oncol 2012; 10: 199-202.

12. Diamond EL, Durham BH, Haroche J, Yao Z, Ma J, Parikh SA, Wang Z, Choi J, Kim E, Cohen-Aubart F, Chun-Wei Lee S, Gao Y, Micol JB, Campbell P, Walsh MP, Sylvester B, Dolgalev I, Aminova O, Heguy A, Zappile P, Nakitandwe J, Ganzel C, Dalton JD, Ellison DW, Estrada-Veras J, Lacouture M, Gahl WA, Stephens PJ, Miller VA, Ross JS, Ali SM, Briggs SR, Fasan O, Block J, Héritier S, Donadieu J, Solit DB, Hyman DM, Baselga J, Janku F, Taylor BS, Park CY, Amoura Z, Dogan A, Emile JF, Rosen N, Gruber TA, Abdel-Wahab O. Diverse and targetable kinase alterations drive histiocytic neoplasms. Cancer Discov 2016;6:154-165.

13. Forest F, N'Guyen A T, Fesselet J, Metellus P, Bouvier C, de Paula AM, Roche PH, Figarella-Branger D. Meningeal Rosai-Dorfman disease mimicking meningioma. Ann Hematol 2014; 93: 937-940.

14. Fukushima T, Yachi K, Ogino A, Ohta T, Watanabe T, Yoshino A, Katayama Y. Isolated intracranial Rosai-Dorfman disease without dural attachment - case report. Neurol Med Chir (Tokyo) 2011; 51: 136-140.

15. Garces S, Medeiros LJ, Patel KP, Li S, Pina-Oviedo S, Li J, Garces JC, Khoury JD, Yin CC. Mutually exclusive recurrent KRAS and MAP2K1 mutations in Rosai-Dorfman disease. Mod Pathol 2017; 30: 1367-1377.
16. Gupta DK, Suri A, Mahapatra AK, Mehta VS, Garg A, Sarkar C, Ahmad FU. Intracranial Rosai-Dorfman disease in a child mimicking bilateral giant petroclival meningiomas: a case report and review of literature. Childs Nerv Syst 2006; 22: 1194-1200.

17. Hadjipanayis CG, Bejjani G, Wiley C, Hasegawa T, Maddock M, Kondziolka D. Intracranial Rosai-Dorfman disease treated with microsurgical resection and stereotactic radiosurgery. Case report. J Neurosurg 2003; 98: 165-168.

18. Hong CS, Starke RM, Hays MA, Mandell JW, Schiff D, Asthagiri AR. Redefining the prevalence of dural involvement in Rosai-Dorfman disease of the central nervous system. World Neurosurg 2016; 90: 702.e13-702.e20.

19. Jabali Y, Smrcka V, Pradna J. Rosai-Dorfman disease: successful long-term results by combination chemotherapy with prednisone, 6-mercaptopurine, methotrexate, and vinblastine: a case report. Int J Surg Pathol 2005; 13: 285-289.

20. Jiang Y, Jiang S. Intracranial meningeal Rosai-Dorfman disease mimicking multiple meningiomas: 3 case reports and a literature review. World Neurosurg 2018; 120: 382-390.

21. Joshi SS, Joshi S, Muzumdar G, Turel KE, Shah RM, Ammbulkar I, Hussain MM, Choudhari KA. Cranio-spinal Rosai Dorfman disease: case series and literature review. Br J Neurosurg 2019; 33: 176-183.

22. Kamisawa T, Zen Y, Pillai S, Stone JH. IgG4-related disease. Lancet 2015; 385: 1460-1471.

23. Khosroshahi A, Wallace ZS, Crowe JL, Akamizu T, Azumi A, Carruthers MN, Chari ST, Della-Torre E, Frulloni L, Goto H, Hart PA, Kamisawa T, Kawa S, Kawano M, Kim MH, Kodama Y, Kubota K, Lerch MM, Löhr M, Masaki Y, Matsui S, Mimori T, Nakamura S, Nakazawa T, Ohara H, Okazaki K, Ryu JH, Saeki T, Schleinitz N, Shimatsu A, Shimosegawa T, Takahashi H, Takahira M, Tanaka A, Topazian M, Umehara H, Webster GJ, Witzig TE, Yamamoto M, Zhang W, Chiba T, Stone JH, Second International Symposium on IgG4-Related Disease. International Consensus Guidance Statement on the Management and Treatment of IgG4-Related Disease. Arthritis Rheumatol 2015; 67: 1688-1699.

24. Kidd DP, Revesz T, Miller NR. Rosai-Dorfman disease presenting with widespread intracranial and spinal cord involvement. Neurology 2006; 67: 1551-1555.

25. Kim M, Provias J, Bernstein M. Rosai-Dorfman disease mimicking multiple meningioma: case report. Neurosurgery 1995; 36: 1185-1187.

26. Krueger EM, Brown HG, Schaible K. Multiple Intracranial Rosai-Dorfman disease: a case report. Cureus 2019; 11: e5292.

27. La Barge DV, 3rd, Salzman KL, Harnsberger HR, Ginsberg LE, Hamilton BE, Wiggins RH, 3rd, Hudgins PA. Sinus histiocytosis with massive lymphadenopathy (Rosai-Dorfman disease): imaging manifestations in the head and neck. AJR Am J Roentgenol 2008; 191: W299-306.

28. Le Guenno G, Galicier L, Fieschi C, Meignin V, Chabrol A, Oksenhendler E. Dramatic efficiency of pegylated interferon in sinus histiocytosis with massive lymphadenopathy. $\mathrm{Br} J$ Dermatol 2011; 164: 213-215.

29. Li Z, Zhou C, Chen G, Bao Y. Intracranial Rosai-Dorfman disease involving the cavernous sinus: a case report and review of the literature. World Neurosurg 2018; 119: 249-255. 
30. Liu L, Perry AM, Cao W, Smith LM, Hsi ED, Liu X, Mo JQ, Dotlic S, Mosunjac M, Talmon G, Weisenburger DD, Fu K. Relationship between Rosai-Dorfman disease and IgG4-related disease: study of 32 cases. Am J Clin Pathol 2013; 140: 395-402.

31. Lüdemann W, Banan R, Samii A, Koutzoglou M, Di Rocco C. Cerebral Rosai-Dorfman disease. Childs Nerv Syst 2015; 31 529-532.

32. Luo Z, Zhang Y, Zhao P, Lu H, Yang K, Zhang Y, Zeng Y. Characteristics of Rosai-Dorfman disease primarily involved in the central nervous system: 3 case reports and review of literature. World Neurosurg 2017; 97: 58-63.

33. McPherson CM, Brown J, Kim AW, DeMonte F. Regression of intracranial rosai-dorfman disease following corticosteroid therapy. Case report. J Neurosurg 2006; 104: 840-844.

34. Menon MP, Evbuomwan MO, Rosai J, Jaffe ES, Pittaluga S. A subset of Rosai-Dorfman disease cases show increased IgG4-positive plasma cells: another red herring or a true association with IgG4-related disease? Histopathology 2014; 64: 455-459.

35. Nalini A, Jitender S, Anantaram G, Santosh V. Rosai-Dorfman disease: case with extensive dural involvement and cerebrospinal fluid pleocytosis. J Neurol Sci 2012; 314: 152-154.

36. Pagel JM, Lionberger J, Gopal AK, Sabath DE, Loeb K. Therapeu tic use of Rituximab for sinus histiocytosis with massive lymphadenopathy (Rosai-Dorfman disease). Am J Hematol 2007; 82: 1121-1122.

37. Petzold A, Thom M, Powell M, Plant GT. Relapsing intracranial Rosai-Dorfman disease. J Neurol Neurosurg Psychiatry 2001; 71: 538-541.

38. Purav P, Ganapathy K, Mallikarjuna VS, Annapurneswari S, Kaly anaraman S, Reginald J, Natarajan P, Suresh Bapu KR, Balamuru gan M. Rosai-Dorfman disease of the central nervous system. J Clin Neurosci 2005; 12: 656-659.

39. Qin G, Ye J, Lan S, Liang Y, Xu P, Tang X, Guo W. Rosai-Dorfman disease with spinal and multiple intracranial involvement a case report and literature review. Br J Neurosurg 2019; 1-5.

40. Raslan OA, Schellingerhout D, Fuller GN, Ketonen LM Rosai-Dorfman disease in neuroradiology: imaging findings in a series of 10 patients. AJR Am J Roentgenol 2011; 196: W187193.

41. Resnick DK, Johnson BL, Lovely TJ. Rosai-Dorfman disease presenting with multiple orbital and intracranial masses. Acta Neuropathol 1996; 91: 554-557.

42. Rivera D, Perez-Castillo M, Fernandez B, Stoeter P. Long-term follow-up in two cases of intracranial Rosai-Dorfman disease complicated by incomplete resection and recurrence. Surg Neurol Int 2014; 5: 30.

43. Russo N, Giangaspero F, Beccaglia MR, Santoro A. Intracranial dural histiocytosis. Br J Neurosurg 2009; 23: 449-454.

44. Sandoval-Sus JD, Sandoval-Leon AC, Chapman JR, Velazquez-Vega J, Borja MJ, Rosenberg S, Lossos A, Lossos IS. Rosai-Dorfman disease of the central nervous system: report of 6 cases and review of the literature. Medicine (Baltimore) 2014; 93: 165-175.

45. Sasidharan A, Verma A, Epari S, Gupta T, Laskar S, Khanna N, Krishnartry R, Bagel B, Jain H, Goda JS. Symptomatic intracranial Rosai-Dorfman disease in the suprasellar region treated with conformal radiotherapy - a report of two cases and literature review. Neurol India 2020; 68: 489-492.
46. Shanmugam V, Margolskee E, Kluk M, Giorgadze T, Orazi A. Rosai-Dorfman disease harboring an activating KRAS K117N missense mutation. Head Neck Pathol 2016; 10: 394-399.

47. Siu RC, Tan IL, Davidson AS, Robertson A, Fraser CL. Clinical reasoning: compressive optic neuropathy secondary to intracranial Rosai-Dorfman disease. Neurology 2015; 85: e89-92.

48. Symss NP, Cugati G, Vasudevan MC, Ramamurthi R, Pande A. Intracranial Rosai Dorfman Disease: report of three cases and literature review. Asian J Neurosurg 2010; 5: 19-30.

49. Tasso M, Esquembre C, Blanco E, Moscardo C, Niveiro M, Paya A. Sinus histiocytosis with massive lymphadenopathy (Rosai-Dorfman disease) treated with 2-chlorodeoxyadenosine. Pediatr Blood Cancer 2006; 47: 612-615.

50. Tauziede-Espariat A, Polivka M, Chabriat H, Bouazza S, Sene D, Adle-Biassette $H$. A case report of meningeal Rosai-Dorfman disease associated with IgG4-related disease. Clin Neuropathol 2015; 34: 343-349.

51. Tian Y, Wang J, Ge J, Ma Z, Ge M. Intracranial Rosai-Dorfman disease mimicking multiple meningiomas in a child: a case report and review of the literature. Childs Nerv Syst 2015; 31 : 317-323.

52. Uetani H, Akter M, Hirai T, Shigematsu Y, Kitajima M, Kai Y, Yano S, Nakamura H, Makino K, Azuma M, Murakami R, Yamashita Y. Can 3T MR angiography replace DSA for the identification of arteries feeding intracranial meningiomas? AJNR Am J Neuroradiol 2013; 34: 765-772.

53. Udono H, Fukuyama K, Okamoto H, Tabuchi K. Rosai-Dorfman disease presenting multiple intracranial lesions with unique findings on magnetic resonance imaging. Case report. J Neurosurg 1999; 91: 335-339.

54. Utikal J, Ugurel S, Kurzen H, Erben P, Reiter A, Hochhaus A, Nebe T, Hildenbrand R, Haberkorn U, Goerdt S, Schadendorf D. Imatinib as a treatment option for systemic non-Langerhans cell histiocytoses. Arch Dermatol 2007; 143: 736-740.

55. Wang C, Kuang P, Xu F, Hu L. Intracranial Rosai-Dorfman disease with the petroclival and parasellar involvement mimicking multiple meningiomas: A case report and review of literature. Medicine (Baltimore) 2019; 98: e15548.

56. Wang L, Li W, Zhang S, Peng L, Shen M, Song S, Zhang W, Cao X, Feng R, Zhang W. Rosai-Dorfman disease mimicking IgG4-related diseases: a single-center experience in China. Orphanet J Rare Dis 2020; 15: 285

57. Wang W, Sun J, Zhang W, Zhou D. Successful treatment of intracranial Rosai-Dorfman disease with cytarabine and dexamethasone: case report and review of literature. Ann Hematol 2020; 99: 1157-1159.

58. Yang X, Liu J, Ren Y, Richard SA, Zhang Y. Isolated intracranial Rosai-Dorfman disease mimicking petroclival meningioma in a child: Case report and review of the literature. Medicine (Baltimore) 2017; 96: e8754.

59. Zhang X, Hyjek E, Vardiman J. A subset of Rosai-Dorfman disease exhibits features of IgG4-related disease. Am J Clin Pathol 2013; 139: 622-632 